
GOVERNMENT AND COMMUNICATION (IJLGC)

WWW.ijlgc.com

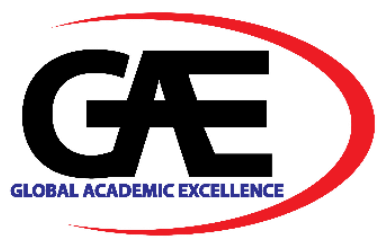

\title{
INFORMAL EMPLOYEE: THEIR IMPORTANCE AND PROTECTION UNDER MALAYSIAN LABOUR LAWS
}

\author{
Azlina Mohd Hussain ${ }^{1}$, Mohd Syahril Ibrahim²*, Anie Farahida Omar ${ }^{3}$ \\ 1 Jabatan Undang-Undang, Universiti Teknologi MARA Cawangan Negeri Sembilan Kampus Seremban \\ Email: azlin072@uitm.edu.my \\ 2 Jabatan Undang-Undang, Universiti Teknologi MARA Cawangan Negeri Sembilan Kampus Seremban \\ Email: syah86@uitm.edu.my \\ 3 Jabatan Undang-Undang, Universiti Teknologi MARA Cawangan Negeri Sembilan Kampus Seremban \\ Email: aniefarahida@uitm.edu.my \\ * Corresponding Author
}

Article Info:
Article history:
Received date: 09.08 .2021
Revised date: 18.08 .2021
Accepted date: 15.09 .2021
Published date: 19.09 .2021
To cite this document:
Hussain, A. M., Ibrahim, M. S., \&
Omar, A. F. (2021). Informal
Employee: Their Importance And
Protection Under Malaysian Labour
Laws. International Journal of Law,
Government and Communication, 6
(25), 64-76.

DOI: $10.35631 /$ IJLGC.625006.

This work is licensed under $\mathrm{CC} B Y 4.0$

(c) (i)

\begin{abstract}
:
This paper aims to address the issue of informal employees in Malaysia. The informal employee is the employee that works for wages in an informal and/ or formal employment setting. Most informal employees have no formal contracts, social benefits, and basic employment legal protection as enjoyed by formal employees. It is important that we identify and address the issues of informal employment as there seems to be an increasing trend towards this kind of employment in the current market economy. The methodology that will be adopted in conducting this study would be a qualitative analysis of all local labour legislations that will provide an insight into the social and legal protection afforded to these informal employees. The findings/ results so far show that none of the local labour legislation provides nor addresses specifically the issues of social and legal protection for the informal employee. We hope to recommend through this paper either specific legislation is created to address the social and legal protection for the informal employee or to propose amendments to the current local labour legislation to incorporate the informal employee in their protection.
\end{abstract}

Keywords:

Informal Employee, Social And Legal Protection, Legislations

\section{Introduction}

In this current market employment, employees tend to vary from the traditionally conservative employments to now more varied and versatile work environment and employment. Employees 


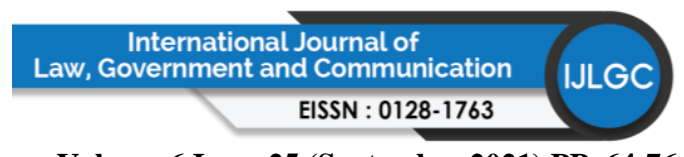

Volume 6 Issue 25 (September 2021) PP. 64-76

DOI 10.35631/IJLGC.625006

are no longer just satisfied with the normal nine to five jobs with the general employment benefits. Due to the rapid development of the global work force, many employees look for more employment that gives them the maximum benefits in terms of quality living, salary, social and medical benefits etc. for themselves as well as for their families (Loayza \& Rigolini, 2011).

With this development, a new breed of employees is fast emerging. These employees are known as the informal employees. Even though this term is not new, always attributed to the lower blue-collar working-class types of jobs, yet these forms of employment is fast gaining ground with the white-collar educated employee sector. The educated, young professionals find this form of employment previously associated as part-time and/ or temporary employment is now gaining popularity even with the younger professionally qualified employees (Axelrad, et.al, 2018). There is a current trend of employment economy known as the free-lancer or gig economy which is closely related to informal employment due to employers engaging contract workers for a temporary period or project-based jobs (non-permanent basis), instead of hiring them for permanent positions. A gig economy is a free market system in which temporary positions are common and organizations contract with independent workers for short-term engagements. The term "gig" is a slang word meaning "a job for a specified period of time" and is typically used in referring to musicians (Istrate \& Harris, 2017).

The objective of this paper is to discuss the current position of Malaysian legislations in relation to informal employees. Preliminary study of Malaysian labour laws suggests that informal employees are not protected under any Malaysian labour legislations. Thus, it is our aim, through a review of relevant Malaysian labour laws, to identity the specific needs and issues of informal employees and possibly recommend for some social and/ or legal protection for informal employees.

\section{Understanding the Concept of Informal Employee, Formal and Informal Sector}

According to Tumin, S. A. (2020), employed persons in Malaysia can be classified into four categories: employer; employee; own account worker also known as self-employed; and unpaid family worker. In 2017, $69.4 \%$ of workers in the informal sector were own account worker, followed by employee $(20.4 \%)$

The informal employees are considered to have informal jobs if their employment relationship is, in law or in practice, not subject to national labour legislation, income taxation, social protection or entitlement to certain employment benefits such as advance notice of dismissal, severance pay, paid annual, sick leave etc (OECD/International Labour Organization (2019). In relation to the informal employee, two sectors of employment are identified, namely the formal sector which represents all jobs with specific working hours and regular wages and the worker's job is assured (Group, S., 2020), and the informal sector which refers to economic activities of workers and entities which are in law or practice not covered by formal arrangements (OECD/International Labour Organization (2019). Informal employees who work in informal sector include food and flea markets, street vendors, laundromats, and the like, mostly in rural or informal areas. It is considered informal since these businesses are rarely registered at national or regional levels, are cash-based, and thus do not pay taxes and usually do not have formal arrangements with employees (Hamilton, B., 2020) 


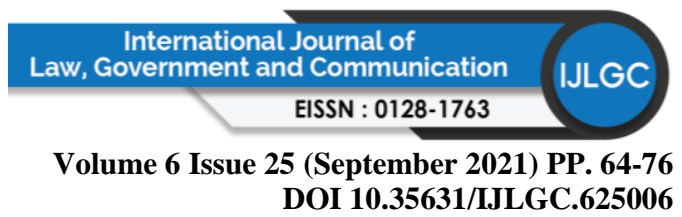

In addition, according to the International Labour Organization (ILO), the informal sector is broadly characterised as consisting of units engaged in the production of goods or services with the primary objective of generating employment and incomes to the persons concerned. These units typically operate at a low level of organisation, with little or no division between labour and capital as factors of production and on a small scale. Labour relations, where they exist, are based mostly on casual employment, kinship, or personal and social relations rather than contractual arrangements with formal guarantees.

Further, the legal definition suggests that the informal economy is the diversified set of economic activities, enterprises, jobs, and workers that are not regulated or protected by the state (Chen, 2012). The concept originally applied to self-employment in small, unregistered enterprises. It has been expanded to include wage employment in unprotected jobs. Wage employment in informal jobs: workers without formal contracts, worker benefits or social protection for formal or informal firms, for households, or those employees with no fixed employer, such as employees of informal enterprises; other informal wage workers (for example, casual or day laborers); domestic workers etc (Chen, 2012).

Market Business News (2020) explains the informal sector, is also known as the underground economy, black economy, or grey economy, is part of a country's economy that is not recognized as normal income sources. People who work in the informal sector do not declare their income and pay no taxes on them. Unlike the formal economy, the informal sector's components are not included in Gross Domestic Product (GDP) computations. This means that countries are probably richer than official statistics suggest.

In Malaysia, the informal sector accounts for 1.36 million employed persons and it accounts for about $9.4 \%$ of the total employment. Majority of them are in the urban area, encompassing around $82 \%$ and growing at about $5 \%$ annually. Their presences are heavily concentrated in the services industry (62.1\%), construction (20.0\%) and manufacturing (17.2\%) (Dass, A.,2020).

The significance in governing informal employee lies in the fact that there is no obligation in law for informal employees to declare their incomes and pay taxes and there is no social protection and entitlements to certain employment rights and benefits viz; notice of termination or dismissal, compensation, paid annual or sick leave etc.

\section{Research Methodology}

Based on the definition of informal employees above, the prevalent theory is that informal employees are not subjected to any national labour legislations. This can be interpreted as informal employees not having any social and/ or legal protection under the law.

Thus, the authors have decided that the relevant research methodology is to study the application of the above theory by conducting a qualitative analysis of all local labour legislations as primary source of Malaysian law to see whether the legislations provide adequate social and legal protection to informal employees. From the study of these legislations, we can identify which legislation provides protection for the informal workers and whether these legislations are adequate and whether further legislations and social framework are needed to provide protection of the informal employees. From there we will be able to 


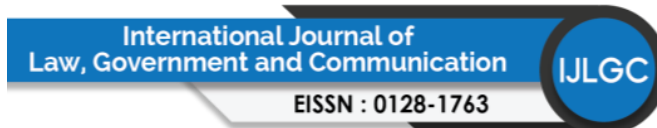

Volume 6 Issue 25 (September 2021) PP. 64-76

DOI 10.35631/IJLGC.625006

better identify or classify the informal workers according to their specific social needs or protection.

\section{Discussion}

The nine (9) principle branches of social security that are generally the concern of most employees, of which they would seek the social and legal protection would be: -

- Employment injury - the concern here would be workers in the construction and agricultural industries especially where work would normally be of temporary or seasonal in nature.

- Sickness - this is a common cause occurrence and side-effects particularly in the factories or industrial waste industries.

- Medical care - often a concern with employees especially with families.

- Invalidity/ disability - also a concern in heavy duty industries where accidents in work occur due to poor or weak health and safety management.

- Survival/ Death - work-related deaths are a concern to be met, especially for the beneficiaries of the deceased.

- Employment - continuous employment or fair working conditions are always a concern among employees.

- Maternity - for women especially those in the informal sector of agriculture this right is especially acute due to the lack of protection for women in informal sectors. Harsh working conditions, dire economic and financial needs would not help to ease the burdens of would-be mothers and/or young mothers.

- Family - the concern here, due to the informal nature of employment would be what would be the rights and benefits of families of the informal workers.

- Old age - and finally the old age retirement benefits are cause of immediate financial concern for the informal employees. For this the retirement social protection needs to be enhanced to meet the growing old age population in the country.

A casual study on Malaysia's statutory and private social protection for workers is met with the discussion and extraction of relevant provisions of the local legislations in respect of the social and legal protection for workers.

\section{The Position of Malaysian Legislations in relation to Informal Employees}

What is generally understood from local legislation/ statute is that while employers can vary the terms of the contracts of service with the mutual consent of the employees, yet employers must provide the basic minimum protection as required under the relevant legislation/ statute and cannot contract out these provisions from the contracts of service even with the mutual consent of the employees.

\section{Employment Act 1955 (EA 1955)}

Currently the EA 1955 is the most effective legislation to measure the scale of legal protection for informal workers.

The relevant provisions extracted are as follows: -

S. 2A - Minister may prohibit employment other than under contract of service - agricultural or industrial undertaking, constructional work, ... 


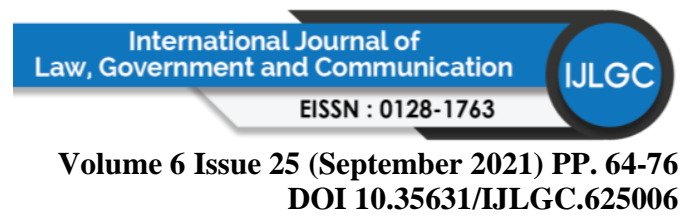

This provision provides for the contract of employment in the agricultural or industrial undertaking. Most informal workers who are the least protected would come from these sectors. The fact that the Minister has powers under the Act to prohibit employment 'other than under a contract of service' provides the legal protection to these workers that they may not be employed unless there is a valid contract of service.

Part II - Contracts of Service - S. 8 (Trade Union), Ss. 10, 11, 12, 13, 14 and 15 (Termination), S. 16 (Employees on estates)

This provision contains the minimum protection for employees i.e. employees are entitled to have contracts of service with their employers. The provisions include favourable conditions to prevail, trade unions, rights to and effects of termination etc. Interesting to note there is a special provision in respect of estate workers. Informal workers in estate or plantations would be able to afford this protection. The reasoning behind this special provision would be the unique and precarious position of estate workers as their hours and days of work is often dictated by the agricultural planning of produce which is normally unpredictable. Thus, the hours, days and wages of estate workers need to be flexible to meet the demands of the agricultural industry.

Part III - Payment of Wages

This provision details the particulars of wage entitlement and payment. The payments are calculated in tables with specific formulas. Informal workers may refer to this Table for payment of wages under their contract of service with their respective employers.

Part VIII - Employment of Women and Part IX - Maternity Protection

The EA 1955 has specific provision for employment of women and maternity protection. Most employers must abide by the general requirements for hiring female employees. Maternity protection is given to eligible female employees.

Part XI - Domestic Servants

A large category of informal employees come in the form of domestic servants. Although there are other specific laws relating to employing foreign workers, yet this provision is unique and addresses specifically the rights of domestic servants. Some relevant provisions are seen from;

Part XII - Rest Days, Hours of Work, Holidays and Other Conditions of Service. The informal worker can also refer to this provision in applying for rest days, hours of work, holidays etc.

Part XIIA - Termination, Lay-Off and Retirement Benefits. This part of the Act governs the provisions for termination, lay-off and retirement benefits.

Part XIIB - Employment of Foreign Employees. This provision addresses generally all employees who are not in the category of domestic servants. The provision would encompass generally all foreign workers whether informal or no and the rights afforded to them under this provision.

Part XIV - Inspection, Part XV - Complaints and Inquiries, Part XVA - Sexual Harassment, 


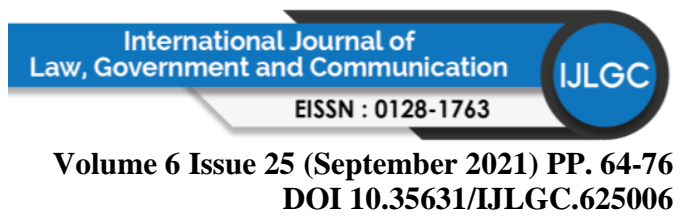

Part XVII - Offences and Penalties - S. 100 - Penalties for failure or non-compliance in relation to rest days, overtime, holidays, annual leave, and sick leave.

The provision for inspection, complaints and inquiries, sexual harassment and offences are all formulated for the protection of the employees. The informal workers especially are best likely to benefit from the protection under these provisions. Their rights and positions are generally very precarious and prone to abuse by their employers. With these protective provisions, employers would be more vary in mistreating their employees especially the informal employees who have no specific formal contracts of service with their employers.

\section{Children and Young Persons (Employment) Act 1966 (CYPE Act 1966)}

This Act is relevant to protect the interests of child-workers. The most vulnerable sector of informal workers would be the child-workers. Unfortunately, most times, the child-workers are not recognized nor captured for the protection under this Act.

The word child in this Act is the one who is not completed 15 years of age and the definition of 'Young Person' is not a child and not completed 18 years of age. Under the Law of Contract, young persons may be liable for certain contracts that they have entered.

Section 2(2) (Employment) has further interpreted and give definition of "light work", public entertainment, Federal Government/ State Government - training in any school, institution, apprenticeship.

Section 3 explains that the Minister has the discretion to prohibit certain kinds of work involving children or young persons. Other relevant provisions to include numbers of days of work (Section 4), hours of work of children (Section 5, hours of work of Young Persons (Section 6) and minimum wages after inquiry (Section 8).

\section{Employment (Termination and Lay-Off Benefits) Regulations 1980 (ELTB 1980)}

This Regulation has stipulated interesting point. For example, Regulation 6 discussed payment of compensation based on how long an employee has worked. Under these Regulations, if an employee has worked for two years or less the employee is entitled to 10 days wages per year. An employee is entitled to 15 days wages if he has worked for two years but less than five years. Beyond that the employee would be entitled to 20 days wages for having worked for more than five years. The payment is prorated if the employee has only worked part of the year. But it still silent as to include the informal employee or not.

\section{Employment (Part-Time Employees) Regulations 2010 (EPTE 2010)}

This EPTE 2010 has touched on the concept of 'casual employment' to which it is introduced into Malaysian legislation for the first time. A 'casual employee' is one engaged occasionally or on an irregular basis, as and when needed, and whose weekly working hours do not exceed $30 \%$ of the weekly working hours of a full-time employee (eg if full-timers work a 48-hour week, casuals work no more than 14.4 hours per week).

As to their 'normal hours of work' for part-time employees, being 'the hours of work as agreed in the contract of service' - or if not so agreed, then certain deeming rules apply. 'Normal hours of work' impact upon when overtime rates kick in on normal days, public holidays, and rest days, and affect the definition of 'ordinary rate of pay'. 


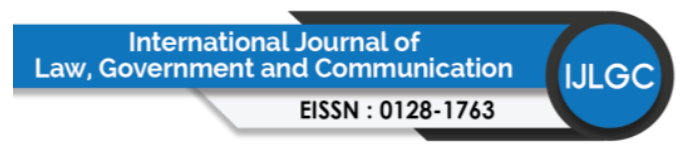

Volume 6 Issue 25 (September 2021) PP. 64-76

DOI 10.35631/IJLGC.625006

The meaning of 'paid overtime' applies where a part-time employee works in excess of their 'normal hours of work'. Special loadings apply where hours exceed the normal hours of work of a full-time employee, as well as for work on public holidays and rest days. As far as the 'Public holidays' is concerned, it is made clear that part-time employees have an entitlement to be paid for public holidays on which they do not work. Payment is to be made at an employee's 'ordinary rate of pay'.

For annual leave, this Regulation provides for annual leave entitlements of part-time employees, again with payment for such leave to be made at the 'ordinary rate of pay'. The quantum of annual leave entitlements is (much like public holidays) set at a fixed amount of 611 days per year depending on length of service. Lastly, for sick leave, it is similar to annual leave, part-time employees are entitled to sick leave of a fixed annual amount (i.e. 10-15 days per annum depending on length of service). Payment is to be made at the employee's 'ordinary rate of pay'.

\section{Employees' Social Security Act 1969 (ESSA 1969)}

Informal workers may seek the protection under this Act, through its SOCSO (Social Security Organisation), which was established in 1971, in providing social security protections to all employees/workers in Malaysia, It provides for some form of protection in terms of employment. It also provides for employer contributions (Part II of the Act), insurance and benefits (Part III of the Act). Also, penalties for errant employers who do not contribute to the protection scheme of their employees. (Part VI of the Act). But still, it is not enough to cater the specific social and legal protection addresses to the informal employees as it not clearly discussed here.

\section{Self-Employment Social Security Act 2017 (SESSA 2017)}

For those informal workers who have no form of contract with their employers a selfemployment form of social security is advised. Here the informal employee provides for his own security independently of his employer. This form of self-protection is gaining ground as more and more workers prefer to work in employments that give them a certain measure of independence and flexibility.

Interesting to note that in most cases now the informal worker may hold more than one job at any given time which makes protection under this scheme highly desirable to the subscribers of this scheme. The Act contains provisions including Benefits (Part IV), Determination, Review and Appeal (Part VI), Financial Provisions (Part VII), The Social Security Tribunal (Part VIII), Enforcement and Investigation (Part IX) and Offences and Penalties (Part X).

\section{Workmen's Compensation Act 1952 (WC Act 1952)}

Of all the legislation and statutes, this particular piece of legislation addresses specifically on employment in construction industry. Most informal workers form a great part of this industry because most times the work is temporary and seasonal. Thus, most employers would not have such lengthy contracts which would protect the rights of the informal workmen in cases of employment related injuries. As in Section 2 has defined the word "workman", however most informal workers must qualify under this definition of "workman" to be able to afford the protection under this statute. Relevant provisions can be seen in Part II (Workmen's Compensation for Injury) and Part III (The Commissioner and Arbitrators). 


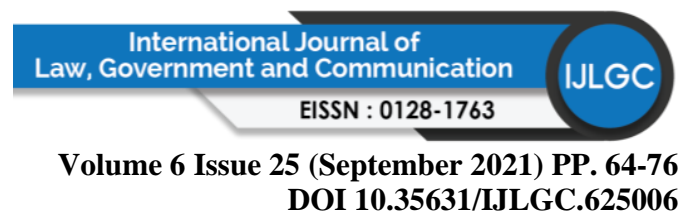

\section{Employees' Provident Fund Act 1991 (EPF Act 1991)}

This Act may seem relevant to the informal employees in getting their social and legal status is protected, especially in Part V (Contributions to the Employees Provident Fund and Part VI (Withdrawal of Contributions).

\section{Employment Insurance System Act 2017 (EIS Act 2017)}

The insurance system recently introduced under this Act that gives the freedom to employees to have their own insurance in the event no protection is afforded by their employers. Interesting to note that this particular statute provides under its insurance scheme a reemployment placement programme for its subscribers. This is an improvement and innovation from the usual benefits afforded by other statutes where generally only monetary compensation is awarded for loss of ability to work.

This statute provides protection in case where employees get retrenched or suffer from loss of work, training and replacement programmes are provided to ensure that the subscribers of the insurance scheme can regain employment. Some relevant provisions are seen from Part IV (Registration and Contributions), Part V (Benefits) and Part VI (Re-employment Placement Programme).

\section{Capital Markets and Services Act 2007 (CMS Act 2007)}

The guideline on Private Retirement Scheme (PRS) are issued by the Securities Commission pursuant to this Act. This guideline was introduced to address the issues of old age retirement and compensation especially for workers who have no formal contract of employment with their employers. This scheme can be benefitted especially by the informal workers since they would have no social protection of the old age retirement fund from their employers.

Generally old age retirement benefits are provided to permanent and long-standing employees in any given organization based on their salary and contributions of years of service. Most informal workers do not have the benefit of enjoying this privilege. That's why the Private Retirement Scheme is so attractive to non-permanent informal workers.

\section{Industrial Relations Act 1967 (IRA 1967)}

This is a good statute that can be referred by the informal employee in enforcing their rights against their employers. Under this Act, informal employees can form Trade Unions for the protection of their rights.

The extracted provisions are as follows: -

- Part II - Protection of Rights of Workmen and Employers and their Trade Unions. This part governs the rights of the informal employees in forming their Trade Unions.

- Part III - Recognition and Scope of Representation of Trade Unions. Generally, this Part outlines the boundaries and jurisdictions of Trade Unions.

- Part IV - Collective Bargaining and Collective Agreements. This part provides for the Collective Agreements formed by the employees which governs the employees' work relationship with the employer. 


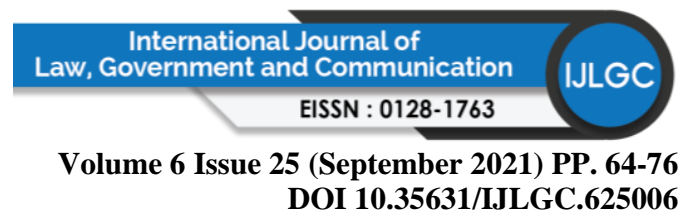

- Part V - Conciliation, Part VI - Representations on Dismissals, Part VII - Industrial Court, Part VIII - Investigation and Inquiry, Part IX - Trade disputes, Strikes and Lockouts, Part IXA - Investigation and Prosecution. The informal worker would enjoy all the rights and benefits under these parts. Conciliation between disputing parties, the right to be represented in cases of dismissal by the employer, the representation in Industrial Court, provisions for investigation and inquiry against abusive and exploitative employers, the right and restrictions to hold trade disputes, strikes and lockout against the employer and the rights for investigation and prosecution for any offences under the IRA 1967.

\section{Trade Unions Act 1959 (TUA 1959)}

This Act governs the conduct of Trade Unions. It is important for employees forming trade unions to understand not only their rights but also their liabilities in forming trade unions (Part IV - Rights and Liabilities of Trade Unions). This statute is relevant so that employees may not abuse the rights, privileges and protection given to them by exploiting the trade unions as means to an end not provided in the statutes and/or legislations. This may run contrary to the purpose under which most labour/ employment laws were enacted and thus would greatly defeat the purpose of which they were created i.e., to provide adequate protection to workers.

\section{Findings/ Results}

The overall findings/ results from the study of legislations and statutes above shows that while there are many protections afforded to the employees, but none specifically address the protection for informal workers. Thus, the current situation is that for those informal employees seeking protection under the law, their only source of protection would be by utilizing the relevant statutes/ legislations which can be made applicable to them, and which can best serve their needs and issues.

\section{Recommendations}

Since there are no legal provisions which specifically protects the rights of informal workers, some other recommendations have been identified to address the issues of protection for the informal workers (Tumin, S. A. (2020)). The protection can be introduced through private insurance schemes, government incentive packages viz, social welfare, health and awareness programmes, employers' initiatives in giving their informal employees better protection, introduction of special employee protection scheme by governing bodies such as the Employees' Provident Fund (EPF) and changes in the current Malaysian labour laws and/ or introduction of a specific legislation governing informal employees in Malaysia.

The details of are as follows: -

Other Protection Initiatives: Governmental and Non-Governmental

Protection initiatives that have been introduced by the Government and/ or non-governmental organizations viz;

- Private Insurance schemes introduced by the Government.

- Initiatives by the Ministry of Health by conducting free health screenings, immunization, awareness programmes to the informal sector of workers etc. 


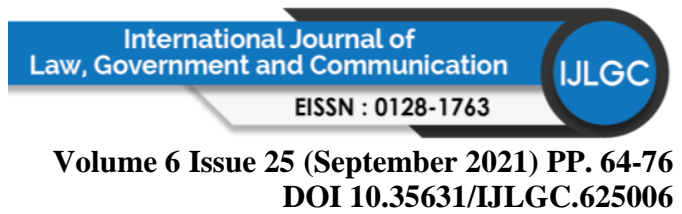

- EPF has taken some independent steps and drawn initiatives to give better social protection to informal workers.

- Employer's scheme where the employers draw specific plans for social and medical benefits and protection for informal workers in their employ.

- The Social Welfare Department has played a significant role in protecting informal workers because it has the capacity to identify informal workers. Generally, the most vulnerable sector of the informal workers tends to come from the low-income group, migrants and children. These sectors of informal workers can be easily identified by the Social Welfare Department as reports of abuse in respect of these groups would be addressed and managed by the Social Welfare Department.

- Government Initiative (BR1M, ekasih), the government has introduced specific payment social welfare schemes to help financially assist the lower income group. These schemes can be benefitted by the informal workers' sector as usually they would comprise of the lower income group sector.

\section{Which Sector Most Affected?}

This is a crucial issue in deciding whether there is a real need for a specific statute or legislation to address the needs of the informal workers. The most vulnerable and least protected informal workers would be from the agriculture industry and small to medium industry These industries tend to employ informal workers as the nature of their work is generally temporary and seasonal in nature. Even working hours and days are dictated by the needs of that specific job economy. Thus, to have long term employment contracts would not generally serve the commercial interests of the employers. Thus, an even balance needs to be identified so that the informal workers in these sectors are protected even when their informal contracts do not provide any or adequate protection.

\section{Cutting Issues}

Generally, the protection that most informal workers seek would be coming from minimum wage, sick leave, paid leave, maternity leave, employer's contribution, and social benefits. The EA 1955 has provisions for all the above rights. Employers, most times would comply with the most minimum protection to enable them to maximize on productivity, cost-saving, and profits. When these happen, oft-times the informal workers would suffer as they would not have the privileges nor the rights of permanent workers to demand for better protection.

\section{Social Protection}

Thus, since the current statutes and legislations are lacking in protection of informal workers, more protection in the form of social and informal means have been identified such as: -

- Awareness - informal workers are given instructions and advice on how best to protect their interests against errant employers. Informal workers are informed of their rights, benefits and how to seek legal redress in cases where their rights have been infringed.

- Employers to be given incentives - there has been some recommendations that to encourage employers to give better protection to their informal employees that employers are given incentives for labour/ employment law compliances. Research have shown a sharp incline indication in increase in productivity when welfare of employees is well taken care of. 


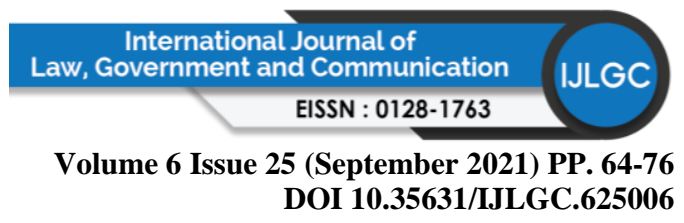

It is hoped that these soft, non-legal approach would be a good short-term solution for the informal workers, while more permanent long-term solutions are being formulated. However, it has been noted that these non-legal approaches serve better the needs of informal workers as the solutions are more practical, speedier, and cheaper than taking the legal approach where informal workers are required to take legal action against their employers to demand for their rights under the relevant labour/ employment laws. Usually, these legal actions would be costly and would take a long time to give the urgent remedy or redress that the informal employee seeks. Thus, most informal workers are prejudiced by the delay in giving the proper remedy or redress so much so that in most cases the informal employees either withdraw their cases against their employers or not seek any remedy or redress at all.

\section{Legal Protection}

Another approach that has been advocated by the concerned employment sector for the protection of informal workers are viz;

- Private contracts - informal employees are encouraged to have written contracts outlining their basic rights and interests under their terms of employment. Having a private written contract or employment package protects informal employees against unlawful termination/ dismissal, non-payment of compensation in cases of injury/ illness/ death and non-access to and/ or rejection of social and medical benefits.

- Government empowered under legislation to check employers for labour/ employment law compliances (EA 1955). Even though relevant laws have been formulated for check and balances of employer related non-compliance yet non-compliances to basic labour/ employment laws and regulations are still being blatantly committed by unscrupulous employers. Harsher and stricter penalties and enforcements have been suggested by the relevant pressure groups and probably will be taken into consideration for early implementation.

A study of the relevant statutes and legislations of other jurisdictions would help us understand better the needs of the informal employee and how best we can provide for their protection.

\section{Conclusion}

The conclusion that can be drawn is that there is a relevant need for a specific legislation to address the issue of the informal employee. Nevertheless, for the time being, there are sufficient statutes, legislations and case precedents that can be applied to the informal employee. Be that as it may, we still need to investigate the specific needs of the informal employee where most legal provisions may not provide for adequate protection of the informal employee as they are more relevant for the formal employee. This research also recommends that relevant statutes and legislations of other jurisdictions to be discussed especially on the status of social and legal protection for informal employee.

\section{References}

Aminuddin, M. (2018). A Practical Approach to Malaysian Employment Law. Ampang, Selangor: Malaysian Current Law Journal.

Aminuddin, M. (2018). Employment Law - Manual for Practitioners, $2^{\text {nd }}$ Edition. Ampang, Selangor: Malaysian Current Law Journal. 


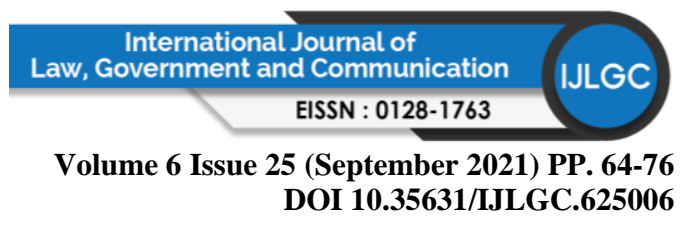

Axelrad, H., Malul, M., \& Luski, I. (2018). Unemployment among younger and older individuals: does conventional data about unemployment tell us the whole story? Journal for labour market research, 52(1), 3. doi:10.1186/s12651-018-0237-9

Balasubramaniam, T. (2017). A Practical Guide to the Industrial Relations Act 1967. Ampang, Selangor: Malaysian Current Law Journal.

Balasubramaniam, T. (2019). Handbook on Workers' Rights. Ampang, Selangor: Malaysian Current Law Journal.

Chandrarajan, S. (2017). The Employment Act 1955: An Annotation. Sweet \& Maxwell Malaysia

Chen, M. A. (2012). The Informal Economy: Definitions, Theories and Policies. Women in Informal Employment: Globalizing and Organizing, 1-22.

Dass, A. (2020, June 9). Informal sector needs a 'New Deal'. The Star. Retrieved September 13, 2021, from https://www.thestar.com.my/business/businessnews/2020/06/09/informal-sector-needs-a-new-deal

D'Cruz, M.N. (2008). Malaysian Employment Laws: Employment Act 1955 (With Annotations and Court Cases) volume 1 \& 2: Kuala Lumpur: Marsden Law Book

Group, S. (2020, March 29). Difference between formal and informal sector in India. Retrieved September 12, 2021, from https://www.sociologygroup.com/formal-informal-sectordifferences/

Hamilton, B. (2020, April 24). Informal sector in dire situation yet contributes billions to economy. $\quad$ Retrieved $\quad$ September 12, 2021, from https://lowvelder.co.za/619561/informal-sector-in-dire-situation-yet-contributesbillions-to-economy/

Informal sector - definition and meaning. Market Business News. (2020, February 9). Retrieved September 14, 2021, from https://marketbusinessnews.com/financialglossary/informal-sector-definition-meaning/.

International Labour Organisation. (1993). Resolution concerning statistics of employment in the informal sector, adopted by the Fifteenth International Conference of Labour Statisticians [Ebook].

Istrate, E., Harris, J. (2017). The Future of Work the Rise of the Gig Economy. Counties Futures Lab, NACO.

Loayza, N. V., \& Rigolini, J. (2011). Informal employment: safety net or growth engine? World Development, 39(9), 1503-1515.

OECD/International Labour Organization (2019), "Definitions of informal economy, informal sector and informal employment", in Tackling Vulnerability in the Informal Economy, OECD Publishing, Paris. DOI: https://doi.org/10.1787/103bf23e-en See https://marketbusinessnews.com/financial-glossary/informal-sector-definitionmeaning/

Suhanah, S. (2012). Employment Law in Malaysia. Lexis Nexis

Tumin, S. A. (2020). (Working paper). Unregistered and "Invisible": Workers in Malaysia's Informal Sector. Kuala Lumpur (pp. 1-46). Kuala Lumpur, Malaysia: Khazanah Research Institute.

\section{Statutes/ Legislations:}

Capital Markets and Services Act 2007

Children and Young Persons (Employment) Act 1966

Employees' Provident Fund Act 1991

Employees' Social Security Act 1969

Employment (Part-Time Employees) Regulations 2010 
Employment (Termination and Lay-Off Benefits) Regulations 1980

Employment Act 1955

Employment Insurance System Act 2017

Industrial Relations Act 1967

Self-Employment Social Security Act 2017

Trade Unions Act 1959

Workmen's Compensation Act 1952 